\title{
Comparing serum levels of cardiac biomarkers in cancer patients receiving chemotherapy and subjects with chronic periodontitis
}

Wings TY Loo ${ }^{1,2}$, Yuan Yue ${ }^{3}$, Chang-bin Fan ${ }^{4}$, Lan-jun Bai ${ }^{5}$, Yi-ding Dou ${ }^{6}$, Min Wang ${ }^{3}$, Hao Liang ${ }^{3}$, Mary NB Cheung ${ }^{6,7}$, Louis WC Chow ${ }^{1 *}$, Jin-le Li ${ }^{5}$, Ye Tian ${ }^{5}$, Liu Qing ${ }^{1}$

From Organisation for Oncology and Translational Research (OOTR) 7th Annual Conference Hong Kong. 13-14 May 2011

\begin{abstract}
Background: Chronic periodontitis (CP) is a chronic inflammation associated with elevations of several inflammatory and cardiac markers. Studies implicated CP as one of the etiologies in coronary heart disease (CHD). Cardiotoxicity is a major complication of anticancer drugs, including anthracyclines and 5-fluorouracil (5FU). The most severe cardiac complications are heart failure, arrhythmia and coronary heart disease (CHD). In this study, we compared the level of inflammatory factors and cardiac markers between chronic periodontitis patients and cancer patients receiving chemotherapy.
\end{abstract}

Methods: 108 blood samples of periodontally healthy subjects were obtained on random from Hong Kong Red Cross, and these represented the controlled population. Forty-four patients diagnosed with chronic periodontitis were recruited from the West China Hospital of Stomatology, Sichuan University. They have received scaling and root planning with mean pocket depths of $6.05 \mathrm{~mm}$. Thirty breast cancer patients diagnosed with invasive ductal carcinoma from UNIMED Medical Institute, Hong Kong gave consent to participate in this study. They received 4 cycles of $500 \mathrm{mg} / \mathrm{m}^{2}$-fluorouracil, $75 \mathrm{mg} / \mathrm{m}^{2}$ epirubicin and $500 \mathrm{mg} / \mathrm{m}^{2}$ cyclophosphamide at a 3-week interval between each cycle. Peripheral venous blood from each group was taken for measurement of blood cells, inflammatory marker (P-selectin, high sensitvity C-reactive protein) and cardiac markers (troponin $\mathrm{T}$; troponin I; $\mathrm{N}$-terminal pro brain natriuretic peptide (Nt-proBNP) and Lactate dehydrogenase (LDH).

Results: The lymphocyte count was higher $(p<0.05)$ in periodontitis patients than the other two groups, and more neutrophils $(p<0.05)$ were seen in cancer patients receiving chemotherapy. The two test groups demonstrated higher levels $(p<0.01$ ) of inflammatory and cardiac markers than the control group.

Conclusions: The elevated cardiac markers found in periodontitis patients suggested that they may carry potential risks in developing cardiac lesions. Troponin T, troponin I, pro-BNP, LDH and high sensitvity C-reactive protein may be used as markers to monitor cardiac lesions in chronic inflammatory patients.

\section{Background}

Gingivitis may lead to periodontitis without proper treatment; the inflammatory periodontal tissues will progress increasingly with age and may lead to pathological destruction of the tooth supporting tissues, tooth

\footnotetext{
* Correspondence: Iwcchow@unimed.hk

'UNIMED Medical Institute, Hong Kong SAR

Full list of author information is available at the end of the article
}

loosening and potential tooth loss [1,2]. The chronic inflammatory periodontal disease, chronic periodontitis $(\mathrm{CP})$, is a common chronic infection with mainly gramnegative bacteria of the tissue surrounding the teeth. Its prevalence increases with increasing age [3]. Most of the adults in the US have periodontal disease, whereas a third of the elderly have moderate to severe periodontal disease [4]. Its common symptoms are bad breath, swollen or bleeding gums, and loose teeth, etc. A comprehensive 
examination is useful for diagnosing periodontitis and designing the treatment plan [5]. Common treatments include surgery, scaling and root planning and medication, however controlling the infection is an effective way of treating periodontitis. Recent studies have shown salivary compounds can be a good biomarker of periodontitis, such as proteins and immunoglobulins have been used and they showed satisfactory results $[6,7]$.

Studies have also suggested a correlation between periodontitis and HIV [8,9]. In 1989 a study was carried out by Mattila and they found that dental health was strongly associated with myocardial infarction (MI) [10]. Others have shown that $\mathrm{CP}$ might be associated with stroke and diabetes $[11,12]$. due to the suppressed immune system. Many studies also suggested that $\mathrm{CP}$ was related to atherosclerosis coronary heart disease (CHD), which is one of the major causes of death in many developed countries [10,13-15]. A meta-analysis suggested a positive correlation (1.14-fold higher risk) between $\mathrm{CP}$ and $\mathrm{CHD}$ even after adjusting the risk factors [16]. Some studies also suggested that the risk of CHD may be lowered by periodontal treatments $[17,18]$. Therefore the relationship between $\mathrm{CP}$ and $\mathrm{CHD}$ has become highly controversial but difficult. The underlying causes of both CP and CHD are complicated because not only genetic factor plays a role, environmental factors are also involved. The traditional risk factors, such as age, sex, smoking, etc., cannot fully explain the causes. In recent decades, many studies have aimed at studying the association between chronic inflammation and CHD.

Cardiac markers are biomarkers which can evaluate the heart function by identifying the blood chemicals that are associated with MI. Lactate dehydrogenase (LDH) is an enzyme that is found in many different types of cells, especially the heart, kidney, liver and muscle. It is involved in energy production, which catalyses the conversion of lactate to pyruvate [19]. The LDH level contains the measurement of five different isoenzymes (LDH-1, LDH-2, LDH-3, LDH-4, and LDH-5) [20], and is released into the blood when the cell dies. Thus, its level can reflect the injury to cells, but it is not used to determine the damaged location. Troponins are proteins that are found in skeletal and cardiac muscle fibres. Troponin $\mathrm{T}$ and troponin I regulate the cardiac muscle contraction [21], they are only released into the blood when there is heart muscle damage. Therefore, they are specific to the heart muscle with a high sensitivity and specificity [22]. N-terminal pro b-type natriuretic peptide (NT pro-BNP) is most concentrated in the left ventricular myocardium. The protein pro-BNP volume remains low under normal conditions. It regulates the blood volume by cleaving itself to release BNP and NT-proBNP. During heart failure, however, the left ventricle works harder and produces more BNP and NT-proBNP [23]. There are high levels of BNP and NT-
proBNP present in acute coronary syndromes and pulmonary thromboembolism [24].

Increased levels of chronic inflammation markers can be observed in CP patients $[25,26]$. The high sensitivity Creactive protein (hs-CRP) level in periodontitis patients increases with the severity of the disease [27]. Hs-CRP became a novel risk factor for $\mathrm{CHD}$ and inflammation in recent years, and some studies have shown a strong association between hs-CRP expression level and increased risk of cardiovascular disease [28-34].

P-selectin is a transmembrane protein, which moves to the endothelial cell surface and recruits leukocytes to the inflammation site. Studies suggested that P-selectin deficiency causes less atherosclerotic lesions [35,36]; therefore, it has been proposed as a platelet activation marker in 1997 [37].

Some studies have suggested periodontitis may have an effect on oral, pancreatic, oesophageal and gastric cancer risk [38-42]. A significant association between breast cancer risk and periodontal disease was suggested by Hujoel [43]; but, Hiraki found no association between breast cancer risk and tooth loss [44]. Invasive ductal carcinoma (IDC) is the most common type of breast cancer. It can be treated by surgery, radiation therapy, anthracycline chemotherapy and hormonal therapy. Anthracyclines have proven to increase survival rates; however, it is accompanied by the adverse effect of cardiotoxicity. Signs of cardiovascular disease were observed in patients receiving fluorouracil [45]; cardiac damages were found in patients receiving cumulative dose of epirubicin [46]. Increased levels of troponin $\mathrm{T}$ were also found at the early anthracycline treatment stage [47].

The aim of this study was to evaluate the association of periodontal disease with CHD by examining the complete blood picture, selected inflammatory markers and cardiac biomarkers in subjects with moderate to severe chronic periodontitis, control subjects and cancer patients who have received chemotherapy.

\section{Methods}

\section{Research subjects recruitment}

108 blood samples of periodontally healthy subjects were recruited on random from Hong Kong Red Cross with their consent and these represented the control population. They underwent detailed oral examination at Keenlink Dental Clinic, Hong Kong. The subjects were determined to be free from the following: systemic or chronic diseases, smoking history, swelling of the lymph nodes, temporal mandibular joint disease, soft tissue abnormalities, severe dental caries, supragingival/subgingival calculus, furcation or generalized gingival recession. Full-mouth clinical parameters were recorded including plaque index, bleeding on probing, probing pocket depth and clinical attachment loss at six sites per teeth according 
to the American Academy of Periodontology in 1999 [48]. The mean pocket depth of these subjects was $2.71 \mathrm{~mm}$ and their clinical attachment loss less than $1 \mathrm{~mm}$ in any one quadrant. None of the subjects were smokers in this study (Table 1).

Forty-four patients diagnosed with chronic periodontitis were recruited from West China Hospital of Stomatology, Sichuan University. The diagnosis of chronic periodontitis was made on the basis of past dental history, clinical parameters and radiographic patterns of alveolar bone loss. They have been suffering from periodontal disease and have received scaling and root planning. The mean pocket depth of these patients was $6.05 \mathrm{~mm}$ (Table 1).

Thirty breast cancer patients were diagnosed with invasive ductal carcinoma from UNIMED Medical Institute, Hong Kong. The age of the patients ranged from 27 to 79 (mean age was 52.6). The clinic-pathological characteristics of breast cancer patients were summarized in Table 2. They were free from other systemic diseases and periodontitis. They had also been examined orally at Keenlink Dental Clinic, Hong Kong. These patients received 4 cycles of $500 \mathrm{mg} / \mathrm{m}^{2} 5$-fluorouracil, $75 \mathrm{mg} / \mathrm{m}^{2}$ epirubicin and $500 \mathrm{mg} / \mathrm{m}^{2}$ cyclophosphamide at a 3-week interval between each cycle. Informed consents were collected before commencement of this study. The experimental protocol has been approved by the ethics committee of Sichuan University and The University of Hong Kong (Protocol No. FEC-DOC-CXB-AB). Their mean pocket depth was $3.6 \mathrm{~mm}$, and clinical attachment loss was less than $1 \mathrm{~mm}$ in any one quadrant.

\section{Cardiac markers measurement}

Peripheral venous blood was taken for complete blood picture for all groups' subjects by a automation blood system (SYSMEX, XS-800i, Japan). The troponin T, troponin I, pro-BNP, and LDH were measured from their serum samples using an automation closed kit system of COBAS INTEGRA 400 PLUS, and ELECSYS 2010 (ROCHE, Germany). The marker levels were obtained by comparing

Table 1 The clinical data (Mean \pm SD) of control subjects and periodontitis patients

\begin{tabular}{lcc}
\hline Clinical parameters & $\begin{array}{c}\text { Control subjects } \\
\mathbf{N}=\mathbf{1 0 8}\end{array}$ & $\begin{array}{c}\text { Periodontitis patients } \\
\mathbf{N}=\mathbf{4 4}\end{array}$ \\
\hline Mean age & $42.90( \pm 9.69)$ & $49.27( \pm 13.63)$ \\
Age range & $18-60$ & $18-74$ \\
Male/Female & $69 / 39$ & $26 / 18$ \\
Mean pocket depth (mm) & $2.71( \pm 1.23)$ & $6.05( \pm 2.74)^{*}$ \\
Bleeding on probing (\%) & $40.26( \pm 9.52)$ & $78.15( \pm 19.76)^{*}$ \\
gingival recession (\%) & $1.0( \pm 1.24)$ & $38.92( \pm 25.88)^{*}$ \\
Supragingival calculus (\%) & $34.14( \pm 13.62)$ & $62.98( \pm 25.84)$ \\
\hline
\end{tabular}

Significant different from the control, ${ }^{*} p<0.05$
Table 2 Clinicopathological characteristics of $\mathbf{3 0}$ breast cancer patients

\begin{tabular}{|c|c|}
\hline & Total number of patients $(\mathrm{N})=30$ \\
\hline Mean age & 52.6 (range: $27-79$ ) \\
\hline \multicolumn{2}{|c|}{ Menopausal status } \\
\hline Premenopausal & 7 \\
\hline Postmenopausal & 23 \\
\hline \multicolumn{2}{|c|}{ Histological Nodal Status } \\
\hline Negative & 26 \\
\hline Positive & 4 \\
\hline \multicolumn{2}{|l|}{ Tumor Size } \\
\hline$\leq 2 \mathrm{~cm}(\mathrm{~T} 1)$ & 15 \\
\hline $2-5 \mathrm{~cm}(\mathrm{~T} 2)$ & 14 \\
\hline$>5 \mathrm{~cm}(\mathrm{~T} 3)$ & 1 \\
\hline \multicolumn{2}{|l|}{ Histology } \\
\hline Ductal & 28 \\
\hline Lobular & 2 \\
\hline \multicolumn{2}{|l|}{ Grading } \\
\hline G1 & 16 \\
\hline $\mathrm{G} 2$ & 12 \\
\hline G3 & 2 \\
\hline \multicolumn{2}{|c|}{ Lymphovascular Permeation } \\
\hline Absence & 26 \\
\hline Presence & 4 \\
\hline \multicolumn{2}{|l|}{ ER Status } \\
\hline Negative & 21 \\
\hline Positive & 9 \\
\hline \multicolumn{2}{|l|}{ PR Status } \\
\hline Negative & 22 \\
\hline Positive & 8 \\
\hline \multicolumn{2}{|l|}{ Her2/neu Status } \\
\hline Negative & 25 \\
\hline Positive & 5 \\
\hline
\end{tabular}

with the standard curve generated from the standards provided by the manufacturer.

\section{Measurement of high sensitivity C-reactive protein and P-selectin}

The High sensitivity C-reactive protein was measured from subjects' serum samples using an automation closed kit system of COBAS INTEGRA 400 PLUS (Roche, Germany). The marker level was also obtained by comparing with the standard curve generated from the standards provided by the manufacturer.

The P-selectin Enzyme-linked immunosorbent assay (ELISA) kit (Roche, Germany) was used. The serum was separated from the blood, centrifuged at 13000 rotations per minute $(\mathrm{rpm})$ prior to the assay. The samples and control-serum were diluted to the following ration: 1:50. After, $100 \mu \mathrm{l}$ of standard solution and serum were pipetted into the appropriate well. $50 \mu \mathrm{l}$ of immunoreagent was added and covered with adhesive cover foil, 
then incubated and shaken at $300 \mathrm{rpm}$ for 1 hour. The buffer was aspirated away, and the plate was washed 3 times ( 1 minute each) with washing buffer. The washing buffer was again aspirated away. $100 \mu \mathrm{l}$ of TMB substrate was added and incubated on a shaker at $300 \mathrm{rpm}$ for 25 minutes at room temperature. $25 \mu \mathrm{l}$ of TMB stop solution was added to each well after colour development was sufficient. It was then incubated for 1 minute on the shaker, and measured within 5 minutes at $450 \mathrm{~nm}$.

The mean levels of cardiac and inflammatory markers were compared using students' T-test (SPSS, 15.0, USA). The level of significance was $\mathrm{p}<0.05$.

\section{Results}

The complete blood picture of various groups is shown in Table 3. All the parameters in healthy controls and CP patients lied within the normal range. In the cancer patient group, the haemoglobin, platelet and lymphocyte levels were below the normal range, but the neutrophil count demonstrated a statistically significant increase $(\mathrm{p}<0.05)$ compared to the other two groups. White blood cell count of the CP group was also significantly higher than the healthy controls $(p<0.05)$. The rest of the parameters remained similar in both $\mathrm{CP}$ and cancer patients.

The means of all markers were significantly higher in $\mathrm{CP}$ and cancer patients $(\mathrm{p}<0.01)$ than the healthy controls (Table 4). Moreover, the level of these markers in the cancer group was higher than CP patients except for Hs-CRP and P-selectin. Although healthy controls demonstrated the lowest level of the markers among the three groups, their LDH and NT pro-BNP levels did not fall in the normal range. In fact, the level of NT pro-BNP in all three groups was lower than the normal range.

\section{Discussion}

Our results showed that chronic periodontitis $(\mathrm{CP})$ was associated with increased serum levels of LDH, troponins T \& I, NT pro-BNP, and P selectin. The underlying mechanisms between $\mathrm{CP}$ and $\mathrm{CHD}$ are not fully understood, but several pathways have been proposed, such as
Table 4 Expression level (Mean \pm SE) of inflammatory and cardiac markers

\begin{tabular}{|c|c|c|c|}
\hline $\begin{array}{l}\text { Cardiac \& } \\
\text { InflammatoryMarkers }\end{array}$ & Groups & $\begin{array}{l}\text { Mean } \\
\text { values }\end{array}$ & $\begin{array}{l}\text { Normal Range \& } \\
\text { Unit }\end{array}$ \\
\hline & 1 & $305( \pm 4.644)$ & \\
\hline \multirow[t]{3}{*}{$\mathrm{LDH}$} & 2 & $\begin{array}{c}485 \\
( \pm 11.272)^{*}\end{array}$ & $240-480 \mathrm{U} / \mathrm{L}$ \\
\hline & 3 & $\begin{array}{c}678 \\
( \pm 33.989)^{*}\end{array}$ & \\
\hline & 1 & $1.03( \pm 0.041)$ & \\
\hline \multirow[t]{3}{*}{ Troponin $\mathrm{T}$} & 2 & $\begin{array}{c}10.47 \\
( \pm 0.407)^{*}\end{array}$ & $<10 \mathrm{ng} / \mathrm{ml}$ \\
\hline & 3 & $\begin{array}{c}18.10 \\
( \pm 0.910)^{*}\end{array}$ & \\
\hline & 1 & $0.19( \pm 0.007)$ & \\
\hline \multirow[t]{3}{*}{ Troponin I } & 2 & $\begin{array}{c}1.88( \pm 0.073) \\
*\end{array}$ & $0-2.0 \mathrm{ng} / \mathrm{ml}$ \\
\hline & 3 & $\begin{array}{c}3.44( \pm 0.173) \\
*\end{array}$ & \\
\hline & 1 & $\begin{array}{c}82.97 \\
( \pm 1.040)\end{array}$ & \\
\hline \multirow[t]{3}{*}{ NT pro-BNP } & 2 & $\begin{array}{c}115.77 \\
( \pm 1.002)^{*}\end{array}$ & $140-320 \mathrm{pg} / \mathrm{ml}$ \\
\hline & 3 & $\begin{array}{c}148.55 \\
( \pm 1.650)^{*}\end{array}$ & \\
\hline & 1 & $0.39( \pm 0.004)$ & \\
\hline \multirow[t]{2}{*}{ P-selectin } & 2 & $\begin{array}{c}1.23( \pm 0.051) \\
*\end{array}$ & $0.6-10 \mathrm{ng} / \mathrm{ml}$ \\
\hline & 3 & $0.91( \pm 0.008)$ & \\
\hline High sensitive & 1 & $0.51( \pm 0.030)$ & \\
\hline C-reactive & 2 & $\underset{*}{2.82( \pm 0.166)}$ & $<5 \mathrm{mg} / \mathrm{L}$ \\
\hline protein & 3 & $3.35( \pm 0.261)$ & \\
\hline
\end{tabular}

Significant difference from control, ${ }^{*} p<0.05$

$1=$ Control subjects $(\mathrm{N}=108) ; 2=$ Periodontitis patients $(\mathrm{N}=44) ; 3=$ Cancer patients $(\mathrm{N}=30)$

periodontal infection, which can have both direct and indirect effects.

Bacteria are an important causative agent in periodontitis. Bacteremia occurs when bacteria enter the

Table 3 Blood picture (Mean \pm SD) of control and test groups

\begin{tabular}{|c|c|c|c|c|c|}
\hline Blood cells & Healthy controls $(\mathrm{N}=108)$ & Periodontitis patients $(\mathrm{N}=44)$ & Cancer patients $(\mathrm{N}=30)$ & Normal range & Units \\
\hline White blood cell & $6.32( \pm 1.11)$ & $5.75( \pm 1.40)$ & $5.37( \pm 1.49)$ & $4.00-11.00$ & $10^{9} / \mathrm{L}$ \\
\hline Red blood cell & $4.47( \pm 0.88)$ & $3.82( \pm 1.06)$ & $4.18( \pm 1.10)$ & $3.8-5.80$ & $10^{12} / \mathrm{L}$ \\
\hline Hemoglobin & $12.5( \pm 4.26)$ & $12.3( \pm 2.69)$ & $9.6( \pm 4.89)$ & $11.5-16.5$ & $\mathrm{~g} / \mathrm{dl}$ \\
\hline Platelet & $319( \pm 86.16)$ & $191( \pm 74.77)$ & $115( \pm 48.52)$ & $150-400$ & $10^{9} / \mathrm{L}$ \\
\hline Neutrophils & $66.9( \pm 0.81)$ & $49.8( \pm 6.64)$ & $79.5( \pm 9.07)$ & $43.7-77.1$ & $\%$ \\
\hline Lymphocytes & $25.4( \pm 3.07)$ & $39.6( \pm 1.48)^{*}$ & $11.4( \pm 1.46)$ & $15-45.8$ & $\%$ \\
\hline Monocyte & $5.7( \pm 0.26)$ & $7.4( \pm 0.48)$ & $7.4( \pm 0.94)$ & $4.7-12.2$ & $\%$ \\
\hline Eosinophil & $1.7( \pm 0.45)$ & $2.7( \pm 0.33)$ & $1.5( \pm 0.43)$ & $0.7-7.0$ & $\%$ \\
\hline Basophil & $0.3( \pm 0.04)$ & $0.5( \pm 0.03)$ & $0.2( \pm 0.04)$ & $0.1-1.2$ & $\%$ \\
\hline
\end{tabular}

Significant different from the control, ${ }^{*} p<0.05$ 
bloodstream from the oral cavity during tooth brushing, normal mastication, after tooth extraction or periodontal treatment, and inflammatory activity of periodontitis [49]. The bacteria then infects epithelial integrity in periodontal pockets [50], and vascular endothelium of the arterial wall. These can lead to tooth loss and trigger a systemic response and atherosclerosis [51,52]. Chronic infection has been reported to be a contribution to atherosclerosis [53].

Periodontal pathogens are associated with MI and CHD by activating mononuclear phagocytes. When the liposaccharide (products of the pathogens) concentrations are low, the secretions of interleukins $1 \alpha$ and $1 \beta$, and tumour necrosis factors increase. These show that cytokines play a role in atherothrombogenesis inflammatory response [54]. The secretion of cytokines also promotes production of lymphocytes $[55,56]$. The white blood cell count was found to be higher in CP patients in our study which is consistent with Shi's study [57].

An increased number of white blood cells is associated with an increased risk of CHD, cardiovascular disease, atherosclerosis, thrombosis, and myocardial ischemia [58-60]. This increase is probably caused by the inflammatory nature of chronic infections [61], and also due to the polymophonuclear leukocytes [62]. As a result of the increased leukocytes, more cells adhere to the endothelial cells of the blood vessels. These eventually decrease the blood flow as well as the red blood cell count [63]. In CP patients, red blood cell count was found to be lower than healthy controls [64]. This indicated that anaemia might play a role in CHD.

Neutrophils are produced in bone marrow and are important for detecting and dispose the microorganisms. The neutrophil level is important when planning dental treatment for cancer patients who have received chemotherapy and radiotherapy, as their bone marrow may well be affected [65]. A neutrophil count may indicate any bacterial proliferation.

On the other hand, some studies have found that people who have been infected with Chlamydia pneumoniae (C. pneumonia) have a higher risk of CHD $[66,67]$. The C. pneumoniae replicates in the macrophages via chewing and tooth brushing; they are then transported to the arteries from the lungs $[68,69]$. Furthermore, recent studies have shown that Aggregatibacter actinomycetemcomitans, Porphyromonas gingivalis, and Prevotella intermedia are able to invade the coronary endothelium, and the first two were also found in atherosclerotic plaque [70,71].

Our results for the cardiac and inflammatory markers are consistent with the existing literature. A study by Bruno Zappacosta found a statistically significant increase in LDH in the periodontal patient group [72]. The association between periodontitis with serum endotoxin/lipopolysaccharides (LPS) and increased troponins have been found in
Goteiner's study [73]. Papapanagiotou found that a significantly increased plasma level of P-selectin was related to periodontitis [74].

Some researchers found that in healthy populations, the hs-CRP could be measured in a lower concentration (range of 0.1 to $10 \mathrm{mg} / \mathrm{L}$ ) than 100-1000-fold of the acute phase infection and inflammation patients, and there were 2 -fold higher hs-CRP concentrations in patients with stable CHD [75]. These results are overall in line with ours (Table 4).

The hs-CRP cut-off point for high-risk of future development of CHD is likely to be $>1.0 \mathrm{mg} / \mathrm{L}$ in a general population of Japanese, and this value is much lower than Western populations [76]. Elevated hs-CRP levels were also found periodontits patients [27].

Cardiac markers are useful in diagnosing acute coronary syndromes [77,78]. Although LDH are concentrated in the heart cells, they are found in nearly all body cells and are released into the bloodstream when the cells are damaged. Therefore, they cannot be used to diagnose particular diseases, such as CHD. Troponins have high specificity and sensitivity; thus, they can be used as a gold standard to detect myocardial damage [79].

In the present study, other confounding factors might to some extent affect the results, as both periodontal disease and CHD share many common risk factors, such as smoking, increased consumption of saturated fat and cholesterol, diabetes, blood pressure, and decreased consumption of vegetables and fruits $[80,81]$.

\section{Conclusions}

Within the limitations concerned above, the present study shows that subjects with chronic periodontitis exhibit significantly higher levels of inflammatory and cardiac biomarkers than the controls. These findings suggest that $\mathrm{CP}$ increases the systemic levels of inflammation and potential risks for CHD. Hence, periodontal disease may represent a modifiable risk factor for CHD.

\section{Abbreviations}

5FU: 5-fluorouracil; C. pneumonia: Chlamydia pneumonia; CP: chronic periodontitis; CHD: coronary heart disease; ELISA: Enzyme-linked immunosorbent assay; hs-CRP: high sensitivity C-reactive protein; IDC: invasive ductal carcinoma; LDH: lactate dehydrogenase; LPS: lipopolysaccharides; Ml: myocardial infarction; Nt-proBNP: N-terminal pro brain natriuretic peptide; rpm: rotations per minute.

\section{Acknowledgements}

This article has been published as part of Journal of Translational Medicine Volume 10 Supplement 1, 2012: Selected articles from the Organisation for Oncology and Translational Research (OOTR) 7th Annual Conference. The full contents of the supplement are available online at http://www.translationalmedicine.com/supplements/10/S1.

\section{Author details}

${ }^{1}$ UNIMED Medical Institute, Hong Kong SAR. ${ }^{2}$ School of Chinese Medicine, Li Ka Shing Faculty of Medicine, The University of Hong Kong, Hong Kong SAR. ${ }^{3}$ State Key Laboratory for Oral Diseases and Department of Prosthodontics, 
West China Hospital of Stomatology, Sichuan University, Sichuan, PR China. ${ }^{4}$ Stomatological Hospital of Guangzhou Medical College, Guangzhou, PR China. ${ }^{5}$ Department of Stomatology, Sichuan Academy of Medical Sciences \& Sichuan Provincial People's Hospital, Chengdu, Sichuan Province, P.R. China. ${ }^{6}$ Jin Hua Dentistry, Chengdu, 610041, Sichuan Province, P.R. China. ${ }^{7}$ Keenlink Dental Clinic, Hong Kong SAR.

\section{Authors' contributions}

WTYL conducted the research, performed data collection and data analysis, and participated in manuscript writing. YY, CF, JL and YT conducted the clinical examination and performed data collection. LB performed data collection and data analysis. MW supervised clinical examination and participated in manuscript planning. $\mathrm{HL}$ performed data analysis and participated manuscript writing. MNBC conducted the clinical examination and participated in manuscript writing. LWCC participated in manuscript planning and writing. All authors read and approved the final manuscript.

\section{Competing interests}

We declare that we have no financial and personal relationships with other people or organizations that can inappropriately influence our work. There is no professional or other personal interest of any nature or kind in any product, service and/or company that could be construed as influencing the position presented in the article entitled, "Comparing serum levels of cardiac biomarkers in cancer patients receiving chemotherapy and subjects with chronic periodontitis".

Published: 19 September 2012

\section{References}

1. Ellen RP: Considerations for physicians caring for older adults with periodontal disease. Clin Geriatr Med 1992, 8:599-616.

2. Cutress TW: Periodontal health in South Pacific populations: a review. Pac Health Dialog 2003, 10:68-75.

3. Albandar JM, Brunelle JA, Kingman A: Destructive periodontal disease in adults 30 years of age and older in the United States, 1988-1994. J Periodontol 1999, 70:13-29.

4. National Institute of Dental Research: Oral health of United States adults, the national survey of oral health in US employed adults and seniors: 1985-86. Bethesda, Maryland: National Institute.

5. Mcleod DE: A practical approach to the diagnosis and treatment of periodontal disease. J Am Dent Assoc 2000, 131:483-491.

6. Kaufman E, Lamster IB: Analysis of saliva for periodontal diagnosis. J Clin Periodontol 2000, 27:453-465.

7. Fine H, Mandel ID: Indicators of periodontal disease activity: an evaluation. J Clin Periodontol 1986, 13:533-546.

8. Black KP, Merrill KW, Jackson S, Katz J: Cytokine profiles in parotid saliva from HIV-1-infected individuals: changes associated with opportunistic infections in the oral cavity. Oral Microbiol Immunol 2000, 15:74-81.

9. Patton LL: Sensitivity, specificity, and positive predictive value of oral opportunistic infections in adults with HIV / AIDS as markers of immune suppression and viral burden. Oral Surg Oral Med Oral Pathol Oral Radiol Endod 2000, 90:182-188.

10. Mattila KJ, Nieminen MS, Valtonen W, et al: Association between dental health and acute myocardial infarction. BMJ 1989, 298:779-782.

11. Beck JD, Offenbacher S: Systemic effects of periodontitis: epidemiology of periodontal disease and cardiovascular disease. J Periodontol 2005, 76(Suppl):2089-2100

12. Nagata T: Relationship between diabetes and periodontal disease. Clin Calcium 2009, 19:1291-1298.

13. Mattila KJ, Valle MS, Nieminen MS, Valtonen W, Hietaniemi KL: Dental infections and coronary atherosclerosis. Atherosclerosis 1993, 103:205-211.

14. Beck J, Garcia R, Heiss G, Vokonas PS, Offenbacher S: Periodontal disease and cardiovascular disease. J Periodontol 1996, 67:1123-1137.

15. DeStefano F, Anda RF, Kahn HS, Williamson DF, Russell CM: Dental disease and risk of coronary heart disease and mortality. BMJ 1993, 306:688-691.

16. Bahekar AA, Singh S, Saha S, Molnar J, Arora R: The prevalence and incidence of coronary heart disease is significantly increased in periodontitis: a meta-analysis. Am Heart J 2007, 154:830-7.

17. Tonetti MS, D'Aiuto F, Nibali L, Donald A, Storry C, Parkar M, Suvan J, Hingorani AD, Vallance $P$, Deanfield J: Treatment of periodontitis and endothelial function. N Engl J Med 2007, 356:911-20.
18. Lösche W: Periodontitis and cardiovascular disease: periodontal treatment lowers plasma cholesterol. South Med J 2007, 100:663-4.

19. Krieg AF, Rosenblum $L J$, Henry JB: Lactate Dehydrogenase Isoenzymes a comparison of pyruvate-to-lactate and lactate-to-pyruvate assays. 1967 13:196-203.

20. Usategui-Gomez M, Wicks RW, Warshaw M: Immunochemical Determination of the Heart Isoenzyme of Lactate Dehydrogenase (LDH1;) in Human Serum. Clin.Chem 1979, 25:729-734.

21. Norman C, Rall JA, Tikunova SB, Davis JP: Modulation of the rate of cardiac muscle contraction by troponin $C$ constructs with various calcium binding affinities. Am J Physiol Heart Circ Physiol 2007, 293 H2580-2587.

22. Ross G, Bever FN, Uddin Z, Hockman EM: Troponin I sensitivity and specificity for the diagnosis of acute myocardial infarction. JAOA 2000, 100:29-32.

23. Elin RJ, Winter WE: Laboratory and Clinical Aspects of B-Type Natriuretic Peptides. Arch Patho Lab Med 2004, 128:697-699.

24. Morrow A.David, Braunwald Eugene: Future of Biomarkers in Acute Coronary Syndromes: Moving Toward a Multimarker Strategy. Circulation 2003, 108:250.

25. D'Aiuto F, Parkar M, Andreou G, Brett PM, Ready D, Tonetti MS: Periodontitis and atherogenesis: causal association or simple coincidence? J Clin Periodontol 2004, 31:402-11.

26. Slade GD, Offenbacher S, Beck JD, Heiss G, Pankow JS: Acute-phase inflammatory response to periodontal disease in the US population. J Dent Res 2000, 79:49-57.

27. Noack B, Genco RJ, Trevisan M, Grossi S, Zambon JJ, De Nardin E: Periodontal infections contribute to elevated systemic C-reactive protein level. J Periodontol 2001, 72:1221-7.

28. Kuller LH, Tracy RP, Shaten J, Meilahn EN: Relation of C-reactive protein and coronary heart disease in MRFIT nested case-control study. Am J Epidemiol 1996, 144:537-547.

29. Tracy RP, Lemaitre RN, Psaty BM, Ives DG, Evans RW, Cushman M, Meilahn EN, Kuller LH, Cushman M, Meilahn EN, Kuller LH: Relationship of C-reactive protein to risk of cardiovascular disease in the elderly: results from the Cardiovascular Health Study and the Rural Health Promotion Project. Arterioscler Thromb Vasc Biol 1997, 17:1121-1127.

30. Ridker PM, Buring JE, Shih J, Matias M, Hennekens $\mathrm{CH}$ : Prospective study of C-reactive protein and the risk of future cardiovascular events among apparently healthy women. Circulation 1998, 98:731-733.

31. Strandberg TE, Tilvis RS: C-reactive protein, cardiovascular risk factors, and mortality in a prospective study in the elderly. Arterioscler Thromb VasC Biol 2000, 20:1057-1060.

32. Danesh J, Wheeler JG, Hirschfield GM, Eda S, Eiriksdottir G, Rumley A, Lowe GD, Pepys MB, Gudnason V: C-reactive protein and other circulating markers of inflammation in the prediction of coronary heart disease. N Engl J Med 2004, 350:1387-1397.

33. Pai JK, Pischon T, Ma J, Manson JE, Hankinson SE, Joshipura K, Curhan GC, Rifai N, Cannuscio CC, Stampfer MJ, Rimm EB: Inflammatory markers and the risk of coronary heart disease in men and women. $N$ Engl J Med 2004, 351:2599-2610.

34. Olsen MH, Sehestedt T, Lyngbaek S, Hansen TW, Rasmussen S, Wachtell K, Torp-Pedersen C, Hildebrandt PR, Ibsen H: Urine albumin/creatinine ratio, high sensitivity $\mathrm{C}$-reactive protein and $\mathrm{N}$-terminal pro brain natriuretic peptide-three new cardiovascular risk markers-do they improve risk prediction and influence treatment? Curr Vasc Pharmacol 2010, 8:134-9.

35. Dong ZM, Brown AA, Wagner DD: Prominent role of P-selectin in the development of advanced atherosclerosis in ApoE-deficient mice. Circulation 2000, 101:2290-2295.

36. Collins RG, Velji R, Guevara NV, Hicks MJ, Chan L, Beaudet AL: P-selectin or intercellular adhesion molecule (ICAM;)-1 deficiency substantially protects against atherosclerosis in apolipoprotein E-deficient mice. J Exp Med 2000, 191:189-194.

37. Blann AD, Lip GY: Hypothesis: is soluble P-selectin a new marker of platelet activation? Atherosclerosis 1997, 128:135-138.

38. Zheng TZ, Boyle P, Hu HF: Dentition, oral hygiene, and risk of oral cancer: a case-control study in Beijing, People's Republic of China. Cancer Causes Control 1990, 1:235-241.

39. Bundgaard T, Wildt J, Frydenberg M, Elbrond O, Nielsen JE: Case-control study of squamous cell cancer of the oral cavity in Denmark. Cancer Causes Control 1995, 6:57-67. 
40. Abnet CC, Qiao YL, Mark SD, Dong ZW, Taylor PR, Dawsey SM: Prospective study of tooth loss and incident esophageal and gastric cancers in China. Cancer Causes Control 2001, 12:847-854.

41. Garrote LF, Herrero R, Reyes RM, et al: Risk factors for cancer of the oral cavity and oro-pharynx in Cuba. Br J Cancer 2001, 85:46-54.

42. Stolzenberg-Solomon RZ, Dodd KW, Blaser MJ, Virtamo J, Taylor PR, Albanes D: Tooth loss, pancreatic cancer, and Helicobacter pylori. Am J Clin Nutr 2003, 78:176-181.

43. Hujoel PP, Drangsholt M, Spiekerman C, Weiss NS: An exploration of the periodontitis-cancer association. Annals of Epidemiology 2003, 13:312-6.

44. Hiraki A, Matsuo K, Suzuki T, Kawase T, Tajima K: Teeth loss and risk of cancer at 14 common sites in Japanese. Cancer Epidemiology Biomarkers \& Prevention: a Publication of the American Association for Cancer Research cosponsored by the American Society of Preventive Oncology 2008, 17:1222-7.

45. Eskilsson J, Albertsson M, Mercke C: Adverse cardiac effects during induction chemotherapy treatment with cis-platin and 5-fluorouracil. Radiother Oncol 1988, 13:41-46.

46. Basser RL, Abraham R, To LB, Fox RM, Green MD: Cardiac effects of highdose epirubicin and cyclophosphamide in women with poor prognosis breast cancer. Ann Oncol 1999, 10:53-58.

47. Kilickap S, Barista I, Akgul E, Aytemir K, Aksoyek S, Aksoy S, Celik I, Kes S, Tekuzman G: CTnT can be a useful marker for early detection of anthracycline cardiotoxicity. Ann Oncol 2005, 16:798-804.

48. Armitage GC: Development of a classification system for periodontal diseases and conditions. Ann Periodontol 1999, 4:1-6.

49. Li X, Kolltveit KM, Tronstad L, Olsen I: Systemic diseases caused by oral infection. Clin Microbiol Rev 2000, 13:547-558.

50. Hujoel PP, Drangsholt M, Spiekerman C, et al: Periodontal disease and coronary heart disease risk. JAMA 2001, 284:1406-10.

51. Fives-Taylor P, Meyer D, Mintz K: Characteristics of Actinobacillus actinomycetemcomitans invasion of and adhesion to cultured epithelial cells. Adv Dent Res 1995, 9:55-62.

52. Lamont RJ, Chan A, Belton CM, Izutsu KT, Vasel D, Weinberg A: Porphyromonas gingivalis invasion of gingival epithelial cells. Infect Immun 1995, 63:3878-3885.

53. Ross R: Atherosclerosis-an inflammatory disease. N. Engl J Med 1999, 340:115-126.

54. Zadeh HH, Nichols FC, Miyasaki KT: The role of the cell-mediated immune response to Actinobacillus actinomycetemcomitans and Porphyromonas gingivalis in periodontitis. Periodontol 2000 1999, 20:239-288.

55. Geerts SO, Nys M, De MP, et al: Systemic release of endotoxins induced by gentle mastication: association with periodontitis severity. J Periodontol 2002, 73:73-78.

56. Beck JD, Slade G, Offenbacher S: Oral disease, cardiovascular disease and systemic inflammation. Periodontol 2000 2000, 23:110-120.

57. Shi D, Meng H, Xu L, Zhang L, Chen Z, Feng X, Lu R, Sun X, Ren X: Systemic inflammation markers in patients with aggressive periodontitis: a pilot study. J Periodontol 2008, 79:2340-2346.

58. Kweider M, Lowe GD, Murray GD, Kinane DF, McGowan DA: Dental disease, fibrinogen and white cell count links with myocardial infarction? Scott Med J 1993, 38:73-74.

59. Fredriksson M, Figueredo C, Gustafsson A, Bergstrom K, Asman B: Effect of periodontitis and smoking on blood leukocytes and acute phase protein. J Periodontol 1999, 70:1355-60.

60. Ensrud K, Grimm RH: The white blood cell count and risk for coronary heart disease. Am Heart J 1992, 124:207-213.

61. Lowe G: Blood rheology in general medicine and surgery. Bailliere's Clin Haematol 1987, 1:827-861.

62. Kowolik MJ, Dowsett SA, Rodriguez J, De La Rosa RM, Eckert GJ: Systemic neutrophil response resulting from dental plaque accumulation. J Periodontol 2001, 72:146-151.

63. Sweetnam PM, Tomas HF, Yarnell JM, Baker IA, Elwood PC: Total and differential leukocyte counts as predictors of ischemic heart disease: The Caerphilly and Speedwell studies. Am J Epidemiol 1997, 145:416-21.

64. Rai B, Kaur J, Kharb S, Jain R, Anand SC, Singh J: Peripheral blood and C-reactive protein levels (CRP) in chronic periodontitis. African Journal of Biochemistry Research 1999, 3:150-153.

65. Glauser MP: Neutropenia: clinical implications and modulation. Intensive Care Med 2000, 26(Suppl 1):103-110.

66. Thom DH, Grayston JT, Siscovick DS, Wang S, Weiss NS, Daling JR: Association of prior infection with Chlamydia pneumoniae and angiographically demonstrated coronary artery disease. JAMA 1992, 268:68-72.

67. Saikku P, Leinonen M, Tenkanen L, Linnanmaki E, Ekman M, Manninen $\mathrm{V}_{\text {, }}$ et al: Chronic Chlamydia pneumoniae infection as a risk factor for coronary heart disease in the Helsinki heart study. Ann Intern Med 1992, 16:273-8.

68. Godzik KL, O'Brien ER, Wang SK, Kuo CC: In vitro susceptibility of human vascular wall cells to infection with Chlamydia pneumoniae. J Clin Microbiol 1995, 33:2411-2414.

69. Kaukoranta-Tolvanen SS, Laitinen K, Saikku P, Leinonen M: Chlamydia pneumoniae multiplies in human endothelial cells in vitro. Microb Pathog 1994, 16:313-319.

70. Kozarov EV, Dorn BR, Shelburne CE, Dunn WA Jr, Progulske-Fox A: Human atherosclerotic plaque contains viable invasive Actinobacillus actinomycetemcomitans and Porphyromonas gingivalis. Arterioscler Thromb Vasc Biol 2005, 25:17-18.

71. Dorn BR, Dunn WA Jr, Progulske-Fox A: Invasion of human coronary artery cells by periodontal pathogens. Infect Immun 1999, 67:5792-5798.

72. Zappacosta B, Manni A, Persichilli S, Boari A, Scribano D, Minucci A, Raffaelli L, Giardina B, De Sole P: Salivary thiols and enzyme markers of cell damage in periodontal disease. Clinical Biochemistry 2007, 40:661-665.

73. Goteiner D, Craig RG, Ashmen R, Janal MN, Eskin B, Lehrman N: Endotoxin levels are associated with high-density lipoprotein, triglycerides, and troponin in patients with acute coronary syndrome and angina: possible contributions from periodontal sources. J Periodontol 2008, 79:2331-9.

74. Papapanagiotou D, Nicu EA, Bizzarro S, Gerdes VE, Meijers JC, Nieuwland R, van der Velden U, Loos BG: Periodontitis is associated with platelet activation. Atherosclerosis 2009, 202:605-11.

75. Ikonomidis I, Andreotti F, Economou E, Stefanadis C, Toutouzas P, Nihoyannopoulos P: Increased proinflammatory cytokines in patients with chronic stable angina and their reduction by aspirin. Circulation 1999, 100:793-798

76. Arima H, Kubo M, Yonemoto K, Doi Y, Ninomiya T, Tanizaki Y, Hata J, Matsumura K, lida M, Kiyohara Y: High-sensitivity C-reactive protein and coronary heart disease in a general population of Japanese: the Hisayama study. Arterioscler Thromb Vasc Biol 2008, 28:1385-91.

77. Antman EM, Tanasijevic MJ, Thompson B: Cardiac-specific troponin I levels to predict the risk of mortality in patients with acute coronary syndromes. N Engl J Med 1996, 355:1342-1349.

78. Alpert JS, the Joint ESC/ACC Committee, et al: Myocardial infarction redefined - a consensus document of the Joint European Society of Cardiology/American College of Cardiology Committee for the redefinition of myocardial infarction. Eur Heart J 2000, 21:1502-1513.

79. Hamm CW, Goldmann BU, Heeschen C: Emergency room triage of patients with acute chest pain by means of rapid testing for cardiac troponin T or troponin I. N Engl J Med 1997, 337:1648-1653.

80. Hujoel P, Drangsholt M, Spiekerman C, DeRouen T: Periodontal disease and coronary heart disease risk. JAMA 2000, 284:1406-1410.

81. Vita JA, Loscalzo J: Shouldering the risk factor burden: infection, atherosclerosis, and the vascular endothelium. Circulation 2002, 106:164-6.

doi:10.1186/1479-5876-10-S1-S5

Cite this article as: Loo et al:: Comparing serum levels of cardiac biomarkers in cancer patients receiving chemotherapy and subjects with chronic periodontitis. Journal of Translational Medicine 2012 10(Suppl 1):S5. 